\title{
Haderslevs, Åbenrås og Sønderborgs krav om dansk retssprog efter 1850
}

\author{
Af $H$. V. Gregersen.
}

Ikke så snart var Treårskrigen kæmpet til ende, før der rejstes krav om, at århundreders misrøgt af det danske sprog skulle ophøre. I Nordslesvig voldte dette onske ingen vanskeligheder, thi det var noget, som den nye øvrighed og landsdelens dansktalende indvånere kunne samstemme i. Kampen om sprogforordningerne mellem de to slesvigske krige kom derfor ikke til at vedrøre det danske Nordslesvig; alligevel kom indførelsen af dansk retssprog til at volde vanskeligheder - ganske vist ikke fra befolkningens side, men derimod fra hertugdømmets øverste retslige instans, Overjustitskommissionen. Sagen var nemlig den, at loven fordrede, at retssproget skulle være blandet, hvor kirke- og skolesproget var både dansk og tysk. Skolesproget blev ret hurtigt rent dansk i Haderslev, Åbenrå og Sønderborg, men kirkesproget vedblev i hele lidsrummet mellem de to slesvigske krige at være blandet, og spørgsmålet om retssproget stod derefter åbent, indtil de lokale myndigheder greb ind.

Det begyndte i Haderslev, hvor dansk allerede den 12. december 1850 var blevet undervisningssprog i Folkeskolen, og inden året var omme, rejste byens magistrat krav om, at dansk også måtte blive byens retssprog. Det skete $i$ følgende udtalelse til $F$. F. v. Tillisch, der var blevet overordentlig regeringskommissær for Slesvig:

Pligtskyldig Indberetning fra Magistraten i Haderslev angaaende det danske Sprogs Anerkjendelse som Retssprog i Haderslev By. Afgivet d. 27de Decbr. 1850.

Det danske Sprog er ved de sildigste Begivenheder mere og mere kommen i sine naturlige Berettigelser i Hertugdømmet Slesvig, og er, hvad Byen Haderslev angaaer, fra et næsten til de nederste Classer fortrængt Sprog, ikke alene bleven Befolkningens 
almindelige Sprog, men ved Deres Excellences (d. e. F. F. v. Tilt lisch) Foranstaltninger nu lovlig anerkjendt som almindeligt Skole- og det fremherskende Kirkesprog.

Ved Rettergangen her i Byen har det danske Sprog i den sildigste Tid ogsala gjort sig gjældende og siden medundertegnede Overauditeur Hammerichs Constitution som Borgmester og Politimester i Haderslev By, er dette Sprog brugt i Retten, og Protocollen fort paa Dansk, med Undtagelse af saidanne Sager, hvori Advocaterne have givet deres Indlag i det lydske Sprog, og hvor denne Omslandighed, af Mangel paia en lovbestemt Regel, gjorde Anvendelsen af det danske Sprog mindre hensigtsmessig, og for den enkelte Sag mindre passende. - Denne Brug af det danske Sprog i Retten har varet en nalurlig Folge af, at nasten Alle, som mode, betjene sig af dette Sprog, og den tidligere brugte Fremgangsmaade, at føre Protocollen paa tydsk, uagtet vedkommende Modende talte dansk, og siden at oplase Protocollen paa dansk, uagtet den vir fort paa tydsk, i hoieste Maade er forkastelig.

Da nu allerede det allerhoieste Rescript af 15de Dec. 1810 bestemmer:

»at i Hertugdømmets Districter, hvor der tales dansk, skal det danske Sprog efterhaanden indføres som Kirke- og Skolesprog, og som det Sprog. der skal bruges ved alle offentlige Anliggender";

og Rescriptet af 26de Mai 1840 udtrykkelig fastsætter:

"at i de Districter i Hertugdømmet, hvor Skole- og Kirkesproget er dansk, skal det danske Sprog bruges i alle Regierings- og Retssager",

saa synes Tiden at være kommen, at det danske Sprog ogsaa retlig bør anerkjendes for at være Rettergangssproget og det Sprog, som skal bruges i alle offentlige Anliggender her i Byen.

$V i$ antage, at der ikke i nogensomhelst Retning kan ligge endog den mindste Vanskelighed i Veien for en saadan Anordning, men ere meget mere overbeviste om, at en satadan Bestemmelse vil blive modtaget med stor Tilfredshed, og tillade os derfor allerrerbødigst at andrage paa, at det maatte behage Deres Excellence at forordne: 
Borgmester Emil Hammerich, Haderslen.

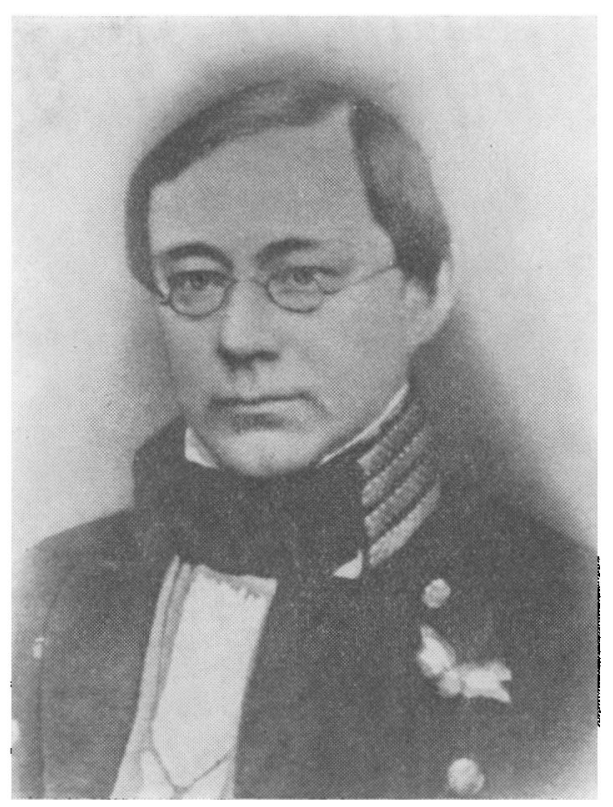

at det danske Sprog for Eftertiden er det i Haderslev Bye gjældende Rettergangs- og $\mathrm{i}$ alle offentlige Anliggender brugelige Sprog.

Allerærbodigst

E. Hammerich

H. Petersen

const.

Til Hs. Excellence, Herr Geheimeconferentsraad Kammerherre v. Tillisch, overordentlig Regjeringscommissair i Hertugdømmet Slesvig, Storkors af Dannebrogen og Dannebrogsmand.'

Ovenstående skrivelse blev ledsaget af en udtalelse af amtmand IV. W. Stockfleth, hvori det meget betegnende hedder, at "Befolkningen ikke mere taaler det tydske Suprematie". og at ansøgningen derfor bør fremmes, så meget mere som sprogforandringerne i kirke og skole var blevet modtaget af befolkningen uden hindringer af nogen art. »Det viser tilstrækkeligen, at Dansk er det Sprog, som her horer hjemme". Overjustitskommissionen anbefalede derefter $\mathrm{i}$ en betæenkning andragendet, og det meddeltes sâ den 8 . febr. 1851, at dansk fremtidigt var rets- og regeringssprog for 
Haderslev by. Pudsigt nok begrundede man dette skridt med, at Kliplev allerede havde fået dansk øvrighedssprog, skønt der her også forekom tyske gudstjenester."

Med et pennestrøg var retssproget altså blevet dansk i Haderslev, men hvad med de andre nordslesvigske købstæder, hvor forholdene var ganske de samme som i Haderslev? Betegnende nok hører man intet fra Tonder by i den anledning. "Hertil var, den nationale vækkelse endnu ikke nảet, i hvert fald ikke danskhedsfølelsen. Men $\mathrm{i}$ alle tre nordslesvigske ostkystbyer var der en levende danskhedsfølelse.

I praksis blev dansk retssprog indført i såvel Ảbenrå som Sønderborg umiddelbart efter, at dansk var blevet skolesprog, og begge steder begrundedes forandringen med sprogreskriptet af 14 . maj 1840. Imidlertid savnedes der stadig en officiel anerkendelse af denne egenmægtigt indforte forandring. Abenra magistrat søgte i en skrivelse af 15 . juli 1851 at få Overjustitskommissionen til at udstede en officiel erklæring herom, men forgæves. Christian Paulsen, som var medlem af Overjustitskommissionen, forklarede i dagbladet "Fædrelandet $",{ }^{4}$ at "en Ret handler efter den bestaaende Retsforfatning, og ikke efter Hensigtsmæssighedsgrundsætninger. Men Commissionen har saa Lidet imod, at Retssproget forandres, at den ikke har gjort Brug af sin Ret til at tilbagevise og hjemstede danske Udfærdigelser og Protokoller fra Aabenraa eller Sønderborg «.

Hele âret 1851 gik uden, at der fra øvrighedens side blev truffet foranstaltninger til en forordning om dansk retssprog $i$ de to dansktalende købstæder Åbenrå og Sønderborg. Den dansksindede befolkning, der gennem århundreders misrogt af hjemmesproget var blevet vannet til at nære mistro mod de ledendes hensigter, følte sig mere og mere brostholden over regeringens langsommelighed på dette punkt; man kunne naturligvis ikke forlange, at folk skulle forstå Christian Paulsens argument. Man havde jo netop oplevet revolutionerende forandringer, og i sådanne tider er man ikke vant til at spørge efter lov og ret. Højst karakteristisk for situationen er derfor det initiativ i sagen, som Ảbenrås deputeretkollegium (de menige byrådsmedlemmer) tog ved at udforme efterstående henvendelse til byens magistrat. Den skal vel også ses på baggrund af den ængstelige folkestemning, der var 
vakt ved den kongelige kundgørelse af 28 . januar 1852 , der beseglede Eider-politikkens nederlag, en følge af de forpligtelser, som Danmark var blevet tvunget til at påtage sig under aftalerne med stormagterne $1851-52$.

\section{Til}

den højtærede Magistrat, hersteds.

Medens der i de sidste Par Aar, fra forskiellige Sider, ere blevne trufne Foranstaltninger, sigtende til at gjøre godt, hvad en forsvunden uretfærdig Tid har syndet imod Folk og Fadreneland med Hensyn til Nationalitet og Folkesprog; medens vor Byes troe og lojale Indvaanere med taknemmelig Glæde anerkjende, hvad der i denne Henseende allerede er bleven udrettet, - hvorledes vore Skoler, ved Indsættelsen af Modersmaalet er bleven "Folkeskoler «, som de forhen rigtignok kaldtes, men paa Grund af det udenlandske Skolesprog ikke vare, - hvorledes Retten og Administrationen i vor Bye, ligeledes taler til Folket i Hjemmets Tungemaal og har aflagt den unaturlige og skadelige Brug af en fremmed Nations Sprog, - hvorledes ogsaa i Kirken Folkesproget vel ikke har faaet Fyldest for sin Ret, men dog er bleven hævet af Fornedrelsen, — ja hvorledes Hans Majestets Regjering ved det Høje Ministerium for vort Hertugdømme udfærdiger danske Bestallinger og Concessioner for vor Bye, -- medens sige vi, disse 'Tegn paa en naturlig Retfærdighed imod os, opfylder Enhver, der meener det redeligt med Konge og Fædreneland, med Tilfredshed og Glæde og styrker Tillid og Troskab, have vi med Beklagelse og ikke uden en bitter Følelse i Hjertet bemærket, hvorledes vort Lands højeste Domstol, Overjustizcommissionen for Hertugdømmet Slesvig, men en for os uforklarlig Haardnakkedhed vedbliver at vise Disens (!) i saa Henseende, i det alle dens Udfærdigelser, ere affattede i det tydske Sprog. Vi vide ikke, og kunde ikke tænke os, hvad Grunden kan være for, at Overjustizcommissionen alene vil fremstille sig, som en Undtagelse, under de ellers hæderlige Almindelige Bestyrelser, at vise den naturligste Retfærdighed imod det Folk der tales til, eller som det vedrører, at bruge dets Sprog. Derimod vide vi, at der er ikkun een Stemme, om denne Overjustizcommissionens Fremgangsmaade, der kun altfor meget minder om de Tider, til hvilke vi med Gru tænker tilbage, - og 
at Ildesindede og Engstlige $\mathrm{i}$ den finde en Levning af hiin Renitenz (opsætsighed), som den meensvorne Embedsstand efter Krigens Ophor benyttede som sidste Støtte for det faldne Oprør.

Med IIensyn til at vort Skolesprog er alene dansk, troe vi ogsaa at kunne have et Krav paa, at erholde danske Rescripter o. s. v. fra Overjustizcommissionen for vort Hertugdømme, der afseet fra alle andre Grunde, sikkerligen aldrig af den Omstændighed, at Kirkesproget her er afvexlende Dansk og Tydsk, - hvilken Omstændighed desforuden ikke er en Retfærdighed, - kan hente Motivet til at holde paa sit tydske Forretningssprog, ligeover for vor danske Bye. Thi skal Skole og Kirkesproget være Kjendemarke, sia ere jo tre Momenter imod og kun eet for det tydske.

Dog vi ansee det for overflødigt at sige meere herom. Vi' nære den Overbeviisning, at den højtærede Magistrat deler vort Ønske om at see Overjustizcommissionen anvende vort eget Sprog, i vore egne Anliggender, og naar vi tillade at fremsende Dette, saa er det for derved at udtale den indstændige Bon om, at den hojlarede Magistrat vil anvende Alt, for at saaledes maa skee.

\section{Frbødigst}

Aabenraa den 17t Marz 1852.

N. Sørensen - 'T. Löbger - Jürg. Cornett - 'Th. Jörgensen C. T. Guldager - H. Jespersen - N. B. Kiölseth - A. Andersen P. Jessen - I. Hansen - Joachim P. Tyroll - I. A. Jürgensen.

Deputeretkollegiets henvendelse til magistraten havde til følge, at borgmester Lunn atter engang mátte tage sagen op, og nedenstående magistratsindstilling af 10 . april 1850 tilstilledes derefter Den Kongelige Overjustitscommission for Slesvig i Flensborg. Det hedder heri:

Under 15. Juli f. A. tillod undertegnede Magistrat sig at henvende sig til Den Kongelige Overjustitscommission med underdanig Bøn om, at høisamme vilde vise os den Bevaagenhed $i$ fremtidige Udfærdigelser til Magistraten hersteds at betjene sig af det danske Sprog. - -

Da det allerede ved det Allerhøieste Rescript af 15. December 1810 er udtrykkeligt befalet,

at i de Districter, Amter og Øer, hvor der tales Dansk, skal det 
Borgmester I. J. J. Lumn, ibenri.

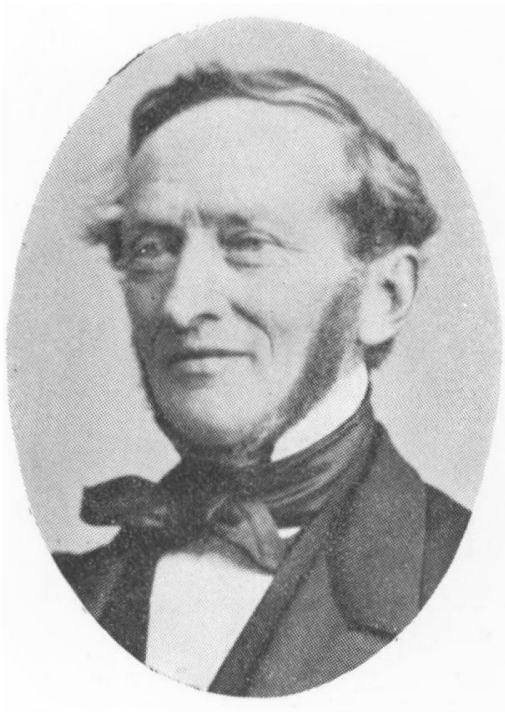

danske Sprog efterhaanden indføres almindeligen ved Gudstjenesten og ved Skoleunderviisningen/ saavelsom ved alle offentlige Anliggender/

da fremdeles det Allerhoiste Rescript af 14 . Mai 1840 indeholder en udtrykkelig Anerkjendelse af del i Sagens Natur iøvrigt tilstrækkeligt begrundede Princip, al Retssproget skal være det samme som Folke, Kirke og Skolesproget,

da det danske Sprog i Medfor af den overordentlige Regjeringscommissairs Resolution af 2 November 1850 er indfort som Underviisningssprog i Byens Skoler, og

da det endelig er en Kjendsgjerning, at den dansktalende Deel tydsktalende, at denne næsten udgjør en forsvindende Storrelse/ ikke fuldt 5 af Hundrede/, og at derhos, selv disse faa Tydsktalende saa godt som uden Undtagelse forstaite Dansk

- troede Magistraten det overflodigt narmere at begrunde den anforte Bøn, idet den ansaae det og fremdeles ansee det for aldeles utvivlsomt, at Byens Befolkning ikke mindre har en lovbegrundet Ret end et naturligt Krav paa at faue Retten pleiet paa det eneste for Alle forstaaelige Sprog, Modersmaalet, hvilken Ret undertegnede Magistrat derhos ogsaa anseer det for en hellig Pligt at værne 
om, og end mindre kan tilstede gjort tvivlsom, da vi derved vilde skuffe den Tillid, som vore Medborgere i saa Henseende oftere har udtalt imod os. -

Just af denne Aarsag havde vi, skjøndt vor Bon af os ubekjendte Grunde blev upaaaglet, ikke fundet os foranledigede til at gjenoptage denne Sag; men da vi troe, at en udtrykkelig Anerkjendelse af denne velbegrundede Ret $\mathrm{i}$ væsentlig Grad vilde bidrage til at hæve den Engstelse og Bekymring, som just i nærrende Tidspunkt sala ofte høres udtalt, at det danske Sprog heller ikke nu skulde komme til fuld Nydelse af sin Ret andensteds end pait Papiret, - en Bekymring, der, hvor ugrundet den end er, dog navnligen her i Byen er saa let forklarlig derved, at det er i Alles friske Minde, hvorledes deres Modersmaal her har været Gjenstand for systematisk Undertrykkelse og Forfølgelse, og da Byens Deputeretcollegium ved et til Magistralen indgivet Andragende af 17. d. M. paa det Indstændigste har lagt os paa Hjerte at virke for, at der, som det i Andragendet hedder, vises den naturligste Retfærdighed imod det Folk, der tales til, at bruge dets Sprog ", have vi dog anseet det for rigtigl, paany at stille den ligesaa underdanige $B$ on som indstændige $B ø n$ til den kongelige Overjustitscommission,

at det matte behage Høisamme i fremtidige Udfardigelser til underlegnede Magistrat at betjene sig af det danske Sprog som Byens Forretningssprog.

Underdanigsl
Lunn, Middelheus, Damm, C. C. Fischer"

Endnu inden Åbenrå magistrat havde fået udarbejdet sit indlæg nr. 2, lod også Sonderborg hore fra sig. Det skete i folgende magistratsskrivelse til Overjustitskommissionen:

Til Den Kongelige Overjustitskommission for Hertugdømmet Slesvig.

Magistraten i Sønderborg By tillader sig herved tjenstærbødigst at henvende sig til Den Kongelige Overjustitskommission for Hertugdømmet Slesvig med følgende Andragende. -

Siden 1ste Januar 1851 har Retssproget heri Byen udelukkende været ført paa Dansk, hvilket Magistraten i Overeensstemmelse 


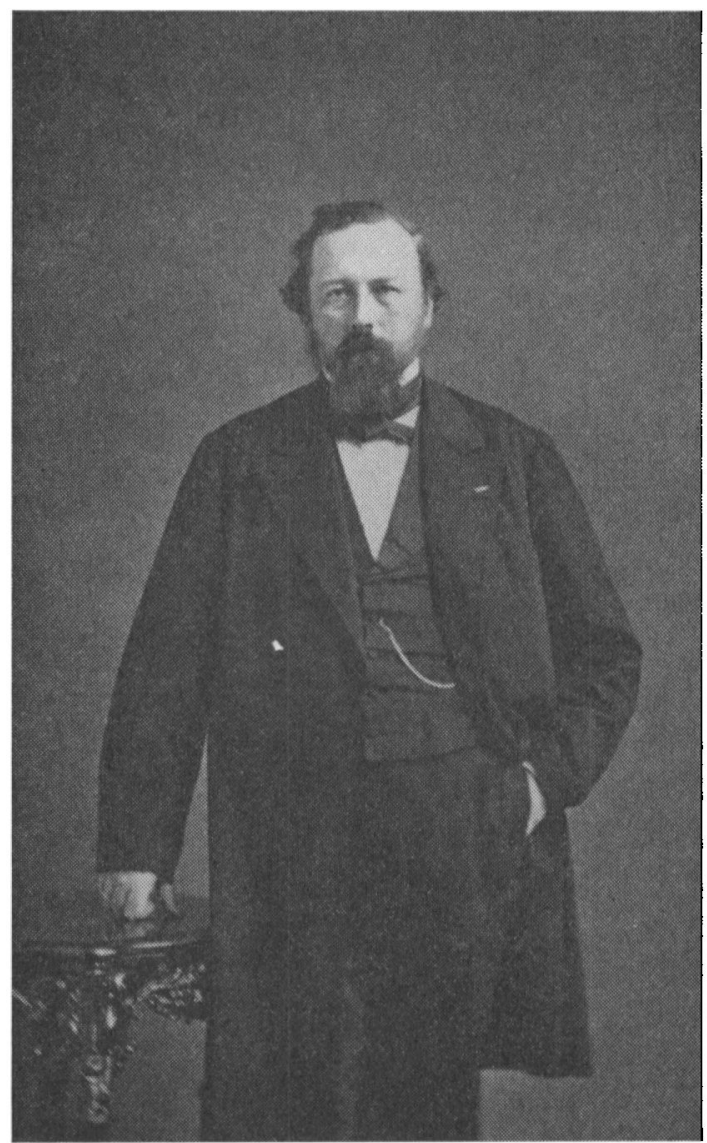

Borgmester IIImar Finsen, Sфnderborg.

med Reskript af 14 Mai 1840 har anseet sig berettiget til, ligesom ogsaa undertegnede Borgermester Finsen, da jeg under 23 Januar f. A. blev konstitueret i dette mit Embede og i den Anledning fremstillede mig for den overordentlige Regjeringskommissair (d. e. F. F. v. Tillisch) og den daværende Chef for Justitsdepartementet (d. e. C. L. E. v. Stemann), paa min Forespørgsel om Retssproget heri Byen var Dansk eller Tydsk, da jeg i sidstnævnte Tilfælde ikke onskede at overtage Konstitutionen, som jeg ikke havde ansøgt, erholdt det Svar, at da Kirke- og Skolesproget heri 
Byen var blandet, var Magistraten bereltiget til at fore Retssproget paa hvilket af disse Sprog, den selv ansalate det hensigtsmaessigt, samt at en Ansogning om at Retssproget heri Byen for Fremtiden maalte blive Dansk ikke ansaaes fornoden. -

Ligesom Magistraten derfor siden den omhandlede 'Tid, da der ikke kan være nogensomhelst Tvivl om, at Folkesproget heri Byen er reent Dansk, og at dette Sprog forstaaes af enhver Indvaaner heri Byen, medens Tydsk ikke benyttes i det daglige Omgangssprog af over 20 Familier, og da endelig Skolesproget heri Byer ved Resolution af Ministeriet for Hertugdømmet Slesvig af 21. Marts $\mathrm{f}$ : A: er hleven udelukkende Dansk, - udelukkende har benytlet det Danske Sprog som Retssprog, og der heraf ikke er opstaat engang den mindste Ulempe, medens vi ere overbeviste om, at Saadant ofte vilde have været Tilfæeldet, natar man havde benyttet det for Menigmand heri Byen fremmede Tydske Sprog, saaledes har ogsala Ministeriet og samtlige Departementer under samme i Udfærdigelser til Magistraten udelukkende benyttet det Danske Sprog, og vi have derfor ikke kunnet antage det for nødvendigt at ansoge om Stadfastelse af en Foranstaltning, hvortil vi efter det Anforte ansalae os berettigede, og som, sata forekom det os, havde erholdt en tilstrakkelig stiltiende Stadfrestelse al' Regjeringen. -

Da den Kongelige Overjustilskommission imidlerlid vedhlivende har benyttet det Tydske Sprog i sine Udfærdigelser lil os, on saaledes ikke kan dele den ovenontalte Anskuelse, kumne vi ikke anlage Andet, end at vi muligen havde feilet i demne, on tillade os. derfor at andrage for den Kongelige Overjustitskommission. al Samme, salafremt det maatte agles fornodent, vil indstille lil Ministeriet for Ilertugdømmet Slesvig:

at det Danske Sprog, som i over 1 Aar faktisk har varet Relssprog i Byen Sonderborg, medens dette Sprog er udelukkende Skole- og Folkesprog heri Byen, udtrykkeligen mat blive stadfastet for Fremtiden som Retssprog. --

Sonderborg d: 28de Marts 1852.

Hilmar Finsen - Christiansen - H. P. Hansen - A. Prehn. ${ }^{7}$

Efter Christian Paulsens ovenfor citerede udtalelse har det ikke været Overjustitskommissionens medlemmer ukært at videre- 


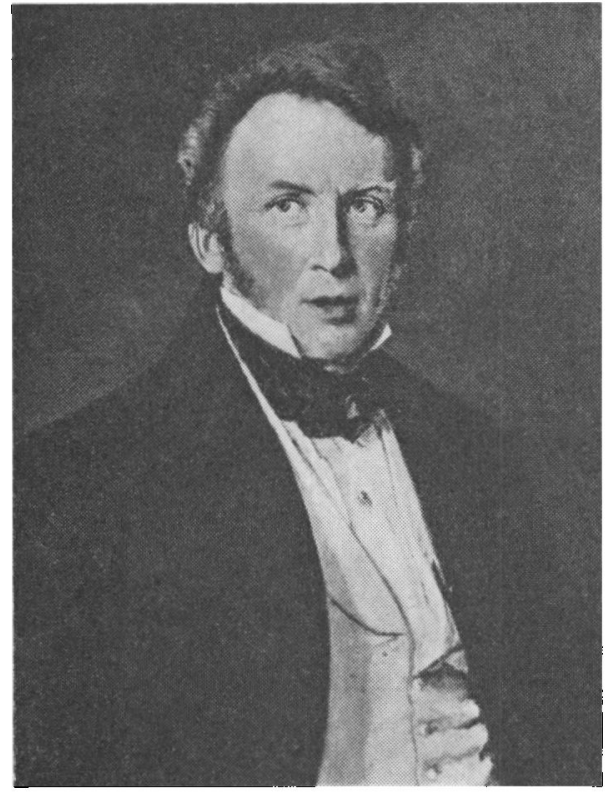

\section{Professor}

Paul Detlev Christian Paulsen,

efter maleri uf

(i. A. Jensen, (ro. 18:0)

Frederiksborg.

befordre ansogningerne om dansk retssprog i de nordslesvigske købstæder til stadfæstelse hos regeringen. I sin anbefaling af andragendet bemarkede Overjustitskommissionen udtrykkeligt, at den havde afventet en almindeligere forholdsregel og derfor ikke selv havde taget initiativet til forandringen. Ministeriet for hertugdømmet Slesvigs svar indløb i form af et kongeligt reskript af $\mathbf{1 6}$. juni 1852 til Appellationsretten, som Overjustitskommissionens navn var siden den 5. maj 1852. Det danske retssprog var dermed lovformeligt anerkendt i Åbenrå sâvel som i Sønderborg, og nogle måneder senere, den 25 . oktober 1852 , fastsattes de nærmere retningslinjer for benyttelsen af enten dansk eller tysk retssprog i Slesvig, bestemmelser, som derefter var gældende indtil $1864 .^{8}$

\section{NOTER:}

1. RA. Min. f. hrtd. Slesvig, 3. dept., > Nyere sprogsager (af Regenburgs saml.).

2. SJy MSkr 1955, s. 125-127.

3. Ganske vist blev spørgsmålet $i$ anl. af et tvivlstilfælde bragt på bane 
af amtmand Reventlow i Tønder, jvf. Hjelholt: Den danske Sprogordning og det danske Sprogstyre mellem Krigene, men der stod ingen folkeopinion bag ved et krav om dansk retssprog $\mathrm{i}$ Tønder, s. 61, jvf. SJy MSkr 19. årg., s. $127 \mathrm{ff}$.

4. Chr. Paulsen: Samlede mindre Skrifter I, s. 33-334 (Fæedrelandet 12. årg. 1851, nr. 216). Om Chr. Paulsens forhold til Overjustitskommissionen se også: Flensborgeren, Professor Christian Paulsens Dagboger (1946), s. 378, 384, 385.

5. LA. Ảbenrå byarkiv, VII 115.

6. Jvf. note 1 og 5.

7. Jvf. note 1.

8. H. Hjelholt: Den danske Sprogordning og det danske Sprogstyre melmel Krigene (1923), s. 61-62. 